\title{
Microscopic, Biochemical, and Molecular Comparisons of Moderately Resistant and Susceptible Populus Genotypes Inoculated with Sphaerulina musiva
}

\author{
Nivi Abraham, ${ }^{1}$ Periasamy Chitrampalam, ${ }^{1}$ Berlin Nelson Jr., ${ }^{1}$ Roshan Sharma Poudel, ${ }^{1}$ Kishore Chittem, ${ }^{1}$ \\ Pawel Borowicz, ${ }^{2}$ Robert Brueggeman, ${ }^{1}$ Shalu Jain, ${ }^{1}$ and Jared Michael LeBoldus ${ }^{3,4, \dagger}$ \\ ${ }^{1}$ Department of Plant Pathology, North Dakota State University, Fargo, ND 58108 \\ ${ }^{2}$ Department of Animal Science, North Dakota State University, Fargo, ND 58105 \\ ${ }^{3}$ Department of Botany and Plant Pathology, Oregon State University, Corvallis, OR 97331 \\ ${ }^{4}$ Department of Forest Engineering Resources and Management, Oregon State University, Corvallis, OR 97331 \\ Accepted for publication 10 August 2019.
}

\begin{abstract}
Sphaerulina musiva, the causal agent of Septoria leaf spot and stem canker, is responsible for mortality and yield loss in Populus plantations. However, little is known about the mode of infection and the mechanisms of resistance in this pathosystem. To characterize these phenomena, microscopic, biochemical, and transcriptome comparisons were performed between leaves of moderately resistant and susceptible genotypes of Populus inoculated with S. musiva conidia. Using scanning electron, cryofracture, and laser-scanning confocal microscopy, the infection and colonization of Populus leaves by $S$. musiva were examined across five time points ( $48 \mathrm{~h}, 96 \mathrm{~h}, 1$ week, 2 weeks, and 3 weeks). The

resistant genotypes were apparent by 1 week postinoculation. However, the germination of conidia was greater on the susceptible than on the moderately resistant genotype $(P<0.008)$. Diaminobenzidine staining, a measure of hydrogen peroxide accumulation, was different $(P<0.001)$ between the host genotypes by 2 weeks postinoculation. Transcriptome differences between genotypes indicated that the speed and amplitude of the defense response were faster and more extensive in the moderately resistant genotype. Changes in gene expression support the microscopic and biochemical observations.
\end{abstract} infection process was similar regardless of the host genotype. Differences in host colonization between susceptible and moderately
Keywords: host-pathogen interaction, Populus spp., Sphaerulina musiva
Populus spp. are model trees used to study physiological aspects of tree biology, including flowering phenology, dormancy, and wood development (He et al. 2010; Hsu et al. 2011; Jansson and Douglas 2007; Meilan 1997; Rennenberg et al. 2010, Tuskan et al. 2006). They also figure prominently in the study of host-microbe interactions that use the genomic resources available for Populus in combination with the reference genomes of their associated microbial species. Examples include Laccaria bicolor (Maire) P.D. Orton (Martin et al. 2008), Melampsora laricis-populina Kleb (Duplessis et al. 2011), Drepanopeziza brunnea (Ellis and Everh.) Rossman and W.C. Allen (Zhu et al. 2012), and Sphaerulina musiva (Peck) Quaedvlieg, Verkley and Crous (Muchero et al. 2018). These reference genomes have set the stage for several studies of reversetranscription RNA-sequencing (RNA-seq) to study gene expression during host-microbe interactions (Azaiez et al. 2009; Dhillon et al. 2015; Foster et al. 2015; Liang et al. 2014; Miranda et al. 2007; Muchero et al. 2018).

In North America, one of the most important diseases of Populus spp. are Septoria leaf spot and stem canker caused by the fungal pathogen $S$. musiva. Stem cankers can reduce growth and cause

${ }^{\dagger}$ Corresponding author: J. M. LeBoldus; jared.leboldus@science.oregonstate.edu

Funding: This study was supported by the DOE Office of Science, Office of Biological and Environmental Research (BER; grant no. DE-SC0018196), and the United States Department of Agriculture National Institute of Food and Agriculture (grant no. USDA-NIFA-RIPM 2012-34103-19771) to J. M. LeBoldus.

*The $\boldsymbol{e}$-Xtra logo stands for "electronic extra" and indicates that one supplementary table is published online.

The author(s) declare no conflict of interest.

(c) 2019 The American Phytopathological Society major stem defects, leading to mortality. Outbreaks of the leaf spot disease can cause premature defoliation and reduce the photosynthetic area of infected leaves, resulting in growth reductions (Feau et al. 2010; Luley and McNabb Jr. 1989; Ostry 1987; Sinclair et al. 1987). The impact of this pathogen has been exacerbated by its relatively recent introduction in the lower mainland of British Columbia, a historically Septoria canker-free region (Callan et al. 2007; Sakalidis et al. 2016). Although the disease is economically and ecologically important, little is known about the infection biology or the genes mediating the host-parasite interaction. The host response to stem colonization has been characterized (Qin and LeBoldus 2014; Weiland and Stanosz 2007); however, no studies have been conducted to examine poplar leaf responses to $S$. musiva infection and colonization.

Two studies have examined the transcriptome of leaves of Populus spp. following inoculation with $S$. musiva. Liang et al. (2014) described transcriptional responses in the leaves of two resistant and two susceptible genotypes 4 days postinoculation (dpi) with $S$. musiva. Defense mechanisms involved in oxidationreduction, protein fate, secondary metabolism, and accumulation of pathogenesis-related gene products were hypothesized to contribute to resistance. In the susceptible genotypes, increased expressions of hypersensitive response loci, particularly those encoding NB-ARC domain-containing proteins, were suggested susceptibility factors. In another study, Foster et al. (2015) noted large differences in the timing and expression of genes among different host-pathogen combinations of Sphaerulina and Populus species. Although expression was typically correlated with the onset of symptom development, no attempt was made to link these differences in the mechanisms of resistance.

Transcriptional changes result in fluctuations in host metabolism and physiology. Often the first change to be detected is an increase 
in reactive oxygen species (ROS) (Lamb and Dixon 1997; Mellersh et al. 2002; Wojtaszek 1997). These ROS can be plant-derived, with a role in defense (Lamb and Dixon 1997; Mellersh et al. 2002; Wojtaszek 1997), or pathogen-derived, with an association with virulence (Shinogi et al. 2003). In biotrophic pathosystems such as powdery mildew on barley (Hückelhoven et al. 1999; ThordalChristensen et al. 1997) or P. striiformis on wheat (Wang et al. 2007), ROS are associated with a hypersensitive response to stop fungal colonization and signal the activation of additional defense responses (Grant and Loake 2000; Hückelhoven et al. 1999; Lamb and Dixon 1997; Levine et al. 1994). In contrast, in necrotrophic pathosystems, ROS enhance pathogen establishment in the host by triggering programmed cell death (Gönner and Schlösser 1993; Govrin and Levine 2000; Tiedemann 1997). Transcriptional responses of the S. musiva-Populus interaction have documented changes in ROSrelated gene expression, but it is unclear whether these changes are correlated with resistance or susceptibility.

To dissect the $S$. musiva-Populus interaction, a better understanding of the biochemical and transcriptional changes in the host following infection is essential. To meet this overarching goal, the following specific objectives were pursued. Using scanning electron microscopy (SEM), cryofracture SEM, and laser-scanning confocal microscopy (LSM) the prepenetration and postpenetration processes were characterized on moderately resistant and susceptible Populus genotypes. The accumulation of $\mathrm{H}_{2} \mathrm{O}_{2}$, measured by diaminobenzidine (DAB) staining, was quantified and correlated with resistance and susceptibility. Global patterns in gene expression of moderately resistant and susceptible Populus genotypes across three time points $(1,2$, and 3 weeks postinoculation) were correlated with anatomical changes observed in the host following inoculation by $S$. musiva.

\section{MATERIALS AND METHODS}

Fungal isolates. Sphaerulina musiva isolates MN14, MN23, and MN32 were collected from Populus spp. located at different planting sites near Garfield, Minnesota $\left(45^{\circ} 56^{\prime} 27.0^{\prime \prime} \mathrm{N}\right.$, $95^{\circ} 29^{\prime} 39.8^{\prime \prime} \mathrm{W}$ ), during the winter of 2012. Cankers were surfacesterilized by soaking them in a $5 \%$ bleach solution $(\mathrm{NaClO} 6 \%$; Homelife Bleach Regular Scent; KIK Custom Products Inc., Chicago, IL) for $2 \mathrm{~min}$, followed by rinsing with sterile distilled water twice. Subsequently, the bark was removed from the margin between necrotic and healthy tissue, and a 4-mm-long piece was removed from the cambium and placed on V8 medium $1.5 \mathrm{~g}$ of $\mathrm{CaCO}_{3}, 137 \mathrm{ml}$ of $\mathrm{V} 8$ juice [Campbell Soup Company, Camden, $\mathrm{NJ}$, $15.2 \mathrm{~g}$ of Difco agar, and $625 \mathrm{ml}$ of deionized water). Necrotic tissue was incubated for 1 week at room temperature, and putative $S$. musiva isolates were subcultured until pure colonies were obtained. Confirmation of the species was based on morphology of the conidia and multilocus genotyping (LeBoldus et al. 2015; Sivanesan 1990). The isolates were stored in $1 \mathrm{ml}$ of a $50 \%$ glycerol solution at $-80^{\circ} \mathrm{C}$. To prepare inoculum, isolates were recovered from storage, poured onto five V8 agar Petri dishes, and allowed to grow for 1 week prior to subculturing on V8 media. Subcultures were incubated for 7 days at room temperature; conidia were harvested by rubbing the surface of the dish with a sterile loop. A spore suspension was made with sterile distilled water and adjusted to $1 \times 10^{6}$ spores $/ \mathrm{ml}$ (LeBoldus et al. 2010).

Transformation of $S$. musiva. S. musiva was transformed with a fluorescent tag to aid visualization by LSM confocal microscopy. Isolate MN14 was grown on five Petri dishes of V8 media for 7 days at room temperature. Conidia were harvested for the transformation protocol. Strain EHA105 of Agrobacterium tumefaciens carrying the binary vector SK2245:pSK2238 with the AsRed and hygromycin $B$ resistance gene was used for transformation. The procedure described by Khang et al. (2006) was used with the following modifications: concentration of acetosyringone $(200 \mathrm{mM})$, hygromycin $250 \mu \mathrm{g} / \mathrm{ml}, 60 \mathrm{~h}$ of incubation in cocultivation media with selection on oatmeal agar (OMA) were used (Foster et al. 2014). Briefly, a conidial suspension of $100 \mu \mathrm{l}$ and Agrobacterium were spread on nitrocellulose membranes placed on cocultivation media. After $60 \mathrm{~h}$, this membrane was placed on OMA containing hygromycin. After 2 to 3 weeks of incubation at room temperature, putative transformants were screened for AsRed expression using a Zeiss AxioObserver Z1 microscope equipped with an LSM 700 (Zeiss, Thornwood, NY) with a 555-nm excitation laser and 570-nm emission. The relative intensity of AsRed transformants was assessed using Zeiss Zen software. Only colonies with intense and uniform expression were transferred with a sterile toothpick to 24-well microtiter plates. The wells contained V8 media with hygromycin $\mathrm{B}$, and colonies were incubated for 5 to 7 days at room temperature. Single spores were harvested from each well containing transformants, grown on V8 amended with hygromycin, and stored at $-80^{\circ} \mathrm{C}$.

Transformants were selected based on phenotypic characterization, pathogenicity testing, and a stability test. Phenotypic characteristics included colony morphology, spore count, and spore size of actively growing transgenic and wild-type $S$. musiva cultures grown on V8 agar. Cultures were incubated for 1 week with three replicates per transformant and wild type. Colony morphology was studied by measuring the colony length and width and observing the color. Spore counts for each transformant and wild type were measured using a hemacytometer. The size of the spores was measured under $10 x$ magnification with an Olympus BX51 microscope (Olympus, Center Valley, PA). Images were captured with a CCD camera (Diagnostic Instruments, Inc., Sterling Height, MI).

Initial pathogenicity testing was conducted on detached leaves of the susceptible genotype NC11505 (P. maximowczii A. Henry $\times$ P. trichocarpa Torr. \& A. Gary ex. Hook). Prior to inoculation, leaves were washed with sterile distilled water twice and placed in Petri dishes (one leaf per dish) that contained wet tissue paper. Leaves were inoculated with one of the following three treatments: a spore suspension of each transformant (R1 to R14) $\left(2 \times 10^{6}\right.$ spore/ $\mathrm{ml})$; the MN14 wild type $\left(2 \times 10^{6}\right.$ spores $\left./ \mathrm{ml}\right)$; or sterile water. There were three replicates of each leaf per transformant. All leaves were sprayed three times with inoculum to ensure uniform coverage. Leaves were incubated at room temperature for 2 weeks.

To select stable transformants from actively growing cultures, 4-mm-diameter mycelial plugs from the culture edges were transferred to V8 Petri dishes. These cultures were incubated for 1 week at room temperature; then, four subsequent subcultures were made at 1-week intervals using the same method. Mycelium from the last subculture was grown in liquid media for 1 week at room temperature and subsequently used for DNA extraction. All DNA extractions were conducted using the Qiagen DNeasy plant mini kit following the manufacturer's protocol. A PCR test was conducted to confirm the stability of these transformants by detecting the hygromycin $B$ resistance gene using the following primer pair: forward TCAGCTTCGATGTAGGAGGG and reverse TTCTACA CAGCCATCGGTCC (El Hadrami et al. 2015). The PCRs were conducted in an Applied Biosystems Veriti 96-well thermal cycler (Life Technologies, Grand Island, NY) in a total volume of $25 \mu \mathrm{l}$ containing $12.5 \mu \mathrm{l}$ GoTaq Green $2 \times$ buffer (Promega, Madison, WI), $1 \mu \mathrm{l}$ of $5 \mu \mathrm{M}$ of each primer, $9.5 \mu \mathrm{l}$ of $\mathrm{H}_{2} \mathrm{O}$, and $2 \mu \mathrm{l}$ of template DNA. The reaction conditions included an initial denaturation step at $94^{\circ} \mathrm{C}$ for $4 \mathrm{~min}, 35$ cycles of $94^{\circ} \mathrm{C}$ for $10 \mathrm{~s}, 62^{\circ} \mathrm{C}$ for $20 \mathrm{~s}$, and $72^{\circ} \mathrm{C}$ for $30 \mathrm{~s}$, followed by a final extension step at $72^{\circ} \mathrm{C}$ for $10 \mathrm{~min}$.

Plant material and host inoculation. Two separate experiments were conducted to characterize the infection, colonization, biochemical, and transcriptional responses of moderately resistant and susceptible genotypes of Populus spp. inoculated with $S$. musiva. In the first experiment, cuttings of the moderately resistant DN99 (Populus deltoides W. Batr. ex Marshall $\times$ P. nigra L.) and the susceptible BESC121 (P. trichocarpa Torr. \& A. Gary ex. Hook) were used for SEM, cryofracture SEM, and RNA-seq. A total of 18 dormant hardwood cuttings for each genotype were obtained from either the Belle River archival plantation in 
Minnesota (DN99) $\left(45^{\circ} 59^{\prime} 44.00^{\prime \prime} \mathrm{N}, 95^{\circ} 12^{\prime} 50.91^{\prime \prime} \mathrm{W}\right)$ or the Department of Energy field planting near Corvallis, Oregon (BESC121) $\left(44^{\circ} 37^{\prime} 22.1^{\prime \prime} \mathrm{N}, 2^{\circ} 07^{\prime} 12.2^{\prime \prime} \mathrm{W}\right)$. These hardwood cuttings were cut to a length of $10 \mathrm{~cm}$, placed in small trays of water, and maintained at room temperature for 2 days. Subsequently, cuttings were planted in SC10 Super cone-tainers (Deepots D40 cell; Stuewe \& Sons Inc., OR) and filled with SunGro growing medium (SunGro Professional Mix \#8; SunGro Horticulture Ltd., MA) combined with slow-release nutricote fertilizer (15-8-12) (N-P-K) (Osmocote Plus; Scotts Company, Ltd., Marysville, $\mathrm{OH})$. When they reached a height of $\approx 30 \mathrm{~cm}$, rooted cuttings were transferred to pots (depth, $22 \mathrm{~cm}$; diameter, $22.5 \mathrm{~cm}$; Stuewe and Sons Tree pot CP59R) that contained SunGro growing medium. Trees were grown in a greenhouse with an 18-h photoperiod augmented with sodium lamps and a $20^{\circ} \mathrm{C}$ (day)/ $16^{\circ} \mathrm{C}$ (night) temperature regime. Trees were fertilized bimonthly with 20-20-20 liquid fertilizer (Scotts Peters Professional).

The goal of the first experiment was to use SEM, cryofracture SEM, and RNA-seq to study the infection process and correlate these observations with transcriptional responses of moderately resistant (DN99) and susceptible (BESC121) Populus genotypes inoculated with $S$. musiva. The experimental design for the first experiment was a randomized complete block design with three blocks. Each genotype (DN99 and BESC121) $\times$ time point combination ( 48 h, 96 h, 1 week, 2 weeks, 3 weeks) occurred once per block. There was also one mock-inoculated control. A total of 36 trees were used in this experiment $(2$ genotypes $\times(5$ time points +1 control) $\times 3$ blocks). Inoculations were conducted by spraying the plants with a mixed conidial suspension of the three aforementioned isolates (MN14, MN23, and MN32). Following inoculations, trees were placed in plastic bags, incubated in the dark for $48 \mathrm{~h}$, and returned to the greenhouse for the remainder of the experiment (LeBoldus et al. 2010). Mock inoculations were conducted in an identical manner except that sterile water rather than a spore suspension was used. Inoculated and symptomatic leaf tissue was collected from each genotype $\times$ time point $\times$ block combination. At the time of inoculation, twist ties were loosely placed around the petiole of the leaf to keep track of the leaves that would be sampled at the end of the experiment. These samples were used for the SEM, cryofracture SEM, and RNA-seq experiments.

The goal of the second experiment was to compare biochemical changes in resistant and susceptible genotypes following infection with $S$. musiva while simultaneously characterizing host colonization with confocal microscopy. In this experiment, DN99 and BESC121 were not available. As a result, DN34 (Populus deltoides W. Batr. ex Marshall $\times$ P. nigra L.), a moderately resistant genotype, and the susceptible genotype NC11505 (P. maximowczii A. Henry $\times$ P. trichocarpa Torr. and A. Gary ex. Hook) were used for confocal microscopy and DAB staining. These genotypes had levels of resistance similar to those of DN99 and BESC121, respectively (Weiland et al. 2003). Ten dormant hardwood cuttings were collected from each genotype at North Dakota State University in Fargo, North Dakota $\left(46^{\circ} 53^{\prime} 36.6^{\prime \prime} \mathrm{N}, 96^{\circ} 48^{\prime} 35.2^{\prime \prime} \mathrm{W}\right)$. There were a total of 20 trees, 10 per genotype ( 5 inoculated +5 mock-inoculated controls). The experimental design was a split plot. The genotypes were considered the whole-plot factor and time was considered the subplot factor. Inoculations were conducted as described, except that leaves were only inoculated with the AsRed-transformed isolate R14. Inoculated and symptomatic leaf tissue was collected from each genotype $\times$ time point $\times$ block combination. The time points included 48 h, 96 h, 1 week, 2 weeks, and 3 weeks postinoculation. Inoculated leaves were randomly selected from a tree at each time point. The same tree was sampled again at a subsequent time point. Control leaves were collected at only the first time point. Samples were used in LSM and DAB staining experiments.

The prepenetration process. Scanning electron microscopy. To examine the prepenetration process of $S$. musiva, segments of leaves from DN99 and BESC121 $(2 \times 2 \mathrm{~cm})$ were collected from the fourth leaf from the top and fourth leaf from the bottom of each plant (i.e., two samples per replicate). Samples were collected at five different time points, $48 \mathrm{~h}$ postinoculation (hpi), $96 \mathrm{hpi}, 1$ week postinoculation (wpi), $2 \mathrm{wpi}$, and $3 \mathrm{wpi}$. The samples collected were fixed in $2.5 \%$ glutaraldehyde in sodium phosphate buffer (Tousimis, Rockville, MD). After washing the leaves in water and buffer, they were desiccated using a graded alcohol series ranging from 30 to $100 \%$ ethanol. An Autosamdri-810 critical-point drier (Tousimis) was used to critical-point dry all samples with liquid carbon dioxide as a transitional fluid. The leaf samples were attached to aluminum mounts with silver paint (SPI Supplies, West Chester, PA) and sputter-coated with gold (Balzers SCD 030; Oerlikon Balzers Coating AG, Balzers, Liechtenstein). Imaging was performed using a JEOL JSm-6490LV scanning electron microscope (Peabody, MA).

The postpenetration process. Cryofracture SEM. Infection and colonization of infected leaf tissue were studied using the same inoculated trees (DN99 and BESC121) as described in the previous section about prepenetration. The fixation procedure was similar to that described previously, with the following exceptions. At the $100 \%$ ethanol stage, leaves in alcohol were frozen in liquid nitrogen and fractured (Moore and Payne 2012). Following an additional change of $100 \%$ ethanol, the leaves were critical-point dried and leaf fragments were attached to aluminum mounts with silver paint. The fractured edge was exposed and sputter-coated with gold. Images were obtained as described above.

Laser scanning confocal microscopy. Five moderately resistant (DN34) and five susceptible (NC11505) trees were inoculated with a spore suspension $\left(2 \times 10^{6}\right.$ spores $\left./ \mathrm{ml}\right)$ of transformant R14. Control trees were sprayed with sterile distilled water. One leaf per tree was randomly collected from the middle section of each tree at $48 \mathrm{hpi}$, 96 hpi, 1 wpi, 2 wpi, and 3 wpi. Control leaves were only collected at the first time point. Images were captured with a Zeiss LSM 700 microscope using a Plan-Apochromat $40 \times / 1.3$ oil immersion lens. To visualize pathogen colonization, Z-stacks of $40-\mu$ m-deep optical sections of leaf tissues including pathogen, stomata, epidermal palisade, and spongy mesophyll tissues were obtained. To visualize leaf tissues, excitation at $605 \mathrm{~nm}$ and emission at $668 \mathrm{~nm}$ were used. The AsRed-tagged pathogen was visualized with excitation and emission spectra of $555 \mathrm{~nm}$ and $570 \mathrm{~nm}$. Images were analyzed for the presence of the pathogen in leaf tissue using Imaris software (Bitplane, Concord, MA). Approximately $200 \mathrm{~h}$ were required to examine all samples with LSM.

In addition, germination of conidia on the moderately resistant (DN34) and susceptible (NC11505) genotypes was compared at $48 \mathrm{hpi}$. For each of the five leaves per genotype, three separate confocal images were recorded from each of three different leaf sections per leaf. The germination percentage was determined from each image and the average germination of conidia was calculated per leaf by considering both germinated and nongerminated spores. A conidium was considered germinated if growth of a germ tube was seen in one or more cells of the spore.

$D A B$ staining. Two segments of leaves $(2 \times 2 \mathrm{~cm})$ were collected from DN34 and NC11505 replicates at each time point and placed in DAB solution $(0.1 \%$; $\mathrm{pH}, 3.8)$. Leaves were incubated in the dark for $4 \mathrm{~h}$ and cleared overnight in an ethanol/chloroform (3:1 vol/vol) trichloroacetic acid solution (0.15\%) (Orczyk et al. 2010). A Zeiss Imager M2 microscope using a Fluor $5 \times / 0.25$ objective and Zeiss AxioCam HRc camera was used to visualize DAB staining on the infected leaf tissues. Hydrogen peroxide is oxidized by DAB producing a brown precipitate. There were five leaf samples for each genotype $\times$ time point combination. For each leaf segment, two sections were viewed and four separate images were taken from each section ( 2 leaf sections $\times 4$ images). The stained and total area were quantified using Image-Pro Premier software (ver. 9.0.1; Media Cybernetics, Inc., Rockville, MD). These values were averaged across the eight subsamples to obtain a single value for each leaf segment. The stained area was expressed as a percentage of the total area. 
Statistical analysis. SAS 9.4 software (SAS Institute, Cary, NC) was used for all analyses, and significance was assessed at $\alpha=0.05$. Germination of conidia on moderately resistant and susceptible genotypes was compared using an unequal variance $t$ test. For DAB comparisons between moderately resistant and susceptible genotypes and within genotypes over time, the area stained was analyzed as a split-plot analysis of variance. Genotypes were considered the whole plot and time was considered the subplot.

Illumina sequencing. The trees in the first experiment (DN99 and BESC121) were sampled for the RNAseq analysis. From those trees at $1 \mathrm{wpi}, 2 \mathrm{wpi}$, and $3 \mathrm{wpi}$, leaf samples showing leaf spots were collected from each replicate, and four individual leaf spots were cut from leaves and placed in lysing matrix tubes. The collected samples were immediately frozen in liquid nitrogen and stored at $-80^{\circ} \mathrm{C}$. mRNA was extracted directly from crude samples using the mRNA Dynabeads Direct Kit (Thermo Fisher Scientific, Waltham, MA) following the manufacturer's protocol with two modifications. Tissue was flash-frozen in liquid nitrogen and disrupted in a bead beater four times for $18 \mathrm{~s}$ each. The tissue was refrozen in liquid nitrogen between disruption steps. An additional step was included in the extraction by adding $0.9 \mathrm{ml}$ of chloroform/isoamyl alcohol to the supernatant obtained after centrifuging the binding solution with lysis. This was vortexed for $30 \mathrm{~s}$ and centrifuged for $5 \mathrm{~min}$ at $14,000 \mathrm{~min}^{-1}$. The supernatant obtained from this step was transferred to tubes containing Dynabeads following the manufacturer's protocol.

The quality and integrity of the mRNA were analyzed using a 2100 Bioanalyzer (Agilent Technologies, Santa Clara, CA) before preparing cDNA libraries. Illumina TrueSeq RNA Library Prep Kit V2 (Illumina, San Diego, CA) was used for library construction. A total of 18 cDNA samples were individually barcoded and run in an Illumina NextSeq 500 sequencer to generate 150-bp single-end reads. The genome and GFF annotation file of Populus trichocarpa v3.0/v10.1 were downloaded from http://popgenie.org/. An analysis of the sequences was performed with CLC Genomics Workbench 8.0 and its default parameters. All the differentially expressed (DE) genes were subjected to a blast search using BLAST2GO. The false discovery rate (FDR)-adjusted $P$-values were obtained using the EDGE bioconductor package available in the CLC Genomics Workbench.

In conventional gene expression studies, genes were selected based on significant differences between treatments; however, Jung et al. (2011) reported that because of stringent FDR-adjusted $P$ values, there is a possibility of disregarding genes that have a large fold change but lack significance. These genes may be relevant in the study of particular biological systems. Therefore, we considered the importance of host genes that are significantly upregulated and downregulated (FDR $\leq 0.01$ ) and/or exhibit a fold change $\geq 3$.

\section{RESULTS}

Transformation of $S$. musiva with red fluorescing protein. The EHA105 A. tumefaciens strain containing the plasmid SK2245:pSK2238 was used to successfully transform $S$. musiva with the AsRed gene (Khang et al. 2006), a variant of the Anemonia sulcata red fluorescing protein (AsRed). A total of 14 transformants, labeled R1 to R14, carrying the AsRed gene were tested for the intensity of red fluorescence. Transformation stability was confirmed by PCR following four consecutive subculturing events. All transformants were stable. Four of the 14 transformants, based on the intensity of red fluorescence and phenotypic characteristics similar to that of the wild-type, were selected for pathogenicity testing. All the transformants produced necrotic lesions typical of S. musiva by 10 dpi. Transformant R14 was selected to study prepenetration and postpenetration events.

Internal and external leaf morphology of the moderately resistant DN99 and susceptible BESC121. Surface morphology of the moderately resistant and susceptible genotypes was similar (Fig. 1A and B). The cryofractured leaf sections of both had a single layer of epidermal cells on the adaxial and abaxial surfaces, two layers of palisade mesophyll cells, loosely packed spongy mesophyll cells, and vascular bundles. The major difference between the genotypes was the well-defined air pockets just above the abaxial epidermis in the susceptible genotype (Fig. 1D). This morphology was absent in the moderately resistant genotype (Fig. 1C).

The prepenetration process. Visualization of conidia, germ tube development, penetration, and hyphal growth on moderately resistant DN99 and susceptible BESC121. There were no differences between genotypes in terms of pathogen attachment or host penetration. Germinating conidia and hyphal growth surrounded by a mucilaginous extracellular matrix (ECM) were seen on the adaxial surface of the leaves by 48 hpi (Fig. 2A). The ECM had a fibrillar structure and was observed at the interface between either conidia or growing hyphae and the leaf surface. This pattern suggested a role in adhesion (Fig. 2B). Germination was either unipolar or multipolar, from one or both ends of the spore, or from a cell in the center (Fig. 2C). There was no pattern in hyphal growth with multiple branching points developing across the leaf surface (Fig. 2D). Frequently, evidence of enzymatic activity was seen as the cuticle around the hyphae appeared eroded (Fig. 2E). Hyphal anastomosis (Fig. 2D and E) and swelling of the conidia (Fig. 2F) were infrequent. From this swelling, germ tubes developed, but there was no evidence that these structures were involved in penetration.

S. musiva penetrated host tissue via stomata or directly through the epidermis (Fig. 3A and E). Penetration of the stomata occurred either from the main germ tube or from the lateral branches. Based on the pattern of growth, there was no evidence that germ tubes or hyphae were attracted directly to stomata. Often hyphae grew across the edges or directly over the stomata without evidence of penetration. Multiple penetrations were occasionally observed (Fig. 3C). At the point of direct penetration through the epidermis, ECM was observed, indicating that this matrix may contain cell wall-degrading enzymes, potentially enabling penetration (Figs. $2 \mathrm{~B}$ and $3 \mathrm{E})$. No differences in the penetration process were observed between genotypes at any of the time points. No evidence of the pathogen was detected on any control leaves.

The postpenetration process. Colonization of moderately resistant DN34 and susceptible NC11505 at 48 hpi. Observations made using LSM were consistent with SEM micrographs. Both stomatal penetration and direct penetration were observed on both genotypes, and there was no evidence of subsequent tissue colonization (Fig. 3B, D, and F). However, a significant difference in the germination percentage $(P<0.008)$ was observed between the moderately resistant $(19.5 \%, n=695)$ and susceptible genotypes $(30.5 \% ; n=1648)$. The pathogen was absent on control leaves of both genotypes.

Colonization of moderately resistant DN99 and DN34 compared with susceptible BESC121 and NC11505 at 96 hpi. Colonization of palisade mesophyll cells began in both moderately resistant and susceptible genotypes, with hyphae observed in the intercellular spaces of both genotypes. Observations made using cryofractured SEM micrographs were consistent with these observations (Fig. 4A and B).

At $1 \mathrm{wpi}$, no visible symptoms were seen on the leaves of the moderately resistant genotype prior to sampling. However, fungal invasion confined to the palisade mesophyll cells was observed microscopically (Fig. 4C and D). Hyphae were present in the intercellular spaces, but there was no evidence of cell death (necrosis) (Fig. 4C and D). In contrast, the susceptible genotype had visible small necrotic lesions on the leaves. The LSM images of the necrotic lesions appeared red, with hyphae visible on the surface. Intercellular colonization of spongy mesophyll cells by $S$. musiva was apparent (Fig. 4E). Cell death, assumed based on red fluorescence, was observed in only a few spongy mesophyll cells (Fig. 4F). The results were consistent between cryofractured SEM micrographs and LSM. 
Small necrotic lesions were observed on the moderately resistant genotype by 2 wpi. Hyphal growth was apparent on the surface of a portion of these lesions. Spongy mesophyll cells below the lesions were at varying stages of cell death and lacked evidence of fungal colonization. However, intercellular hyphae were present around some cells (Fig. 5B). The leaf surface of the susceptible genotype was covered with coalescing necrotic lesions of various sizes. Transformed hyphae were visible on the surface of all the lesions, and intercellular hyphae continued to ramify between the living spongy mesophyll cells (Fig. 5D). These observations were consistent when using LSM and cryofracture SEM (Fig. 5A, E, and F).

Necrotic lesions appeared slightly larger at 3 wpi than at 2 wpi on the moderately resistant genotype. Similar to observations at $2 \mathrm{wpi}$, sparse colonization of the lesion surface by hyphae was apparent, and the spongy mesophyll tissue below each lesion was dead, without any detectable hyphae on the LSM or the cryofracture SEM images (Fig. 5C). In contrast, the susceptible genotype had large coalesced necrotic lesions on all leaves, with extensive intercellular colonization of the living spongy mesophyll layer apparent on both LSM and cryofracture SEM images (Fig. 5D, E, and F). In addition, cryofracture SEM revealed the presence of intracellular colonization of the spongy mesophyll cells (Fig. 5F).

$D A B$ staining of moderately resistant DN34 and susceptible $N C 11505$. Visualization of $\mathrm{H}_{2} \mathrm{O}_{2}$ production as a dark brown color associated with $\mathrm{DAB}$ was observed on the inoculated leaves but not on the control leaves (Fig. 6A and B). There was no statistical difference in the mean area of DAB staining between genotypes at 1 wpi (Fig. 6C and D). However, significant differences were observed at 2 wpi $(P<0.001)$ and 3 wpi $(P<0.001)$, with a greater proportion of the stained area in the susceptible genotype (Figs. 6E, F, and 7).

Transcriptome comparison of moderately resistant DN99 and susceptible BESC121. A total of 1.04 billion reads were generated using an Illumina NextSeq 500 sequencer, with an average read length of $150 \mathrm{bp}$. For each sample, $85 \%$ of the reads in the susceptible genotype and $74 \%$ of the reads in the moderately resistant genotype were mapped to the Populus reference genome. The total number of differentially expressed genes in common between the genotypes was 10,984 genes at 1 wpi, 6,654 genes at 2 wpi, and 7,459 genes at 3 wpi. A total of 1,751 genes were upregulated and 713 genes were downregulated in response to $S$. musiva infection across all three time points in both genotypes. Supplementary Table S1 contains a list of 341 genes that are significantly upregulated and downregulated (FDR $\leq 0.01)$ and 239 genes that exhibit a fold change $\geq 3$ in this study.

Following infection, several genes involved in cell wall modification were differentially expressed in both genotypes. In the moderately resistant genotype, there was a peak in the expression of 52 genes annotated for cell wall modeling, including the following: cellulose synthase-like D1; beta glucosidase; polygalacturonase 4; pectin lyase-like super family; Laccase 17;
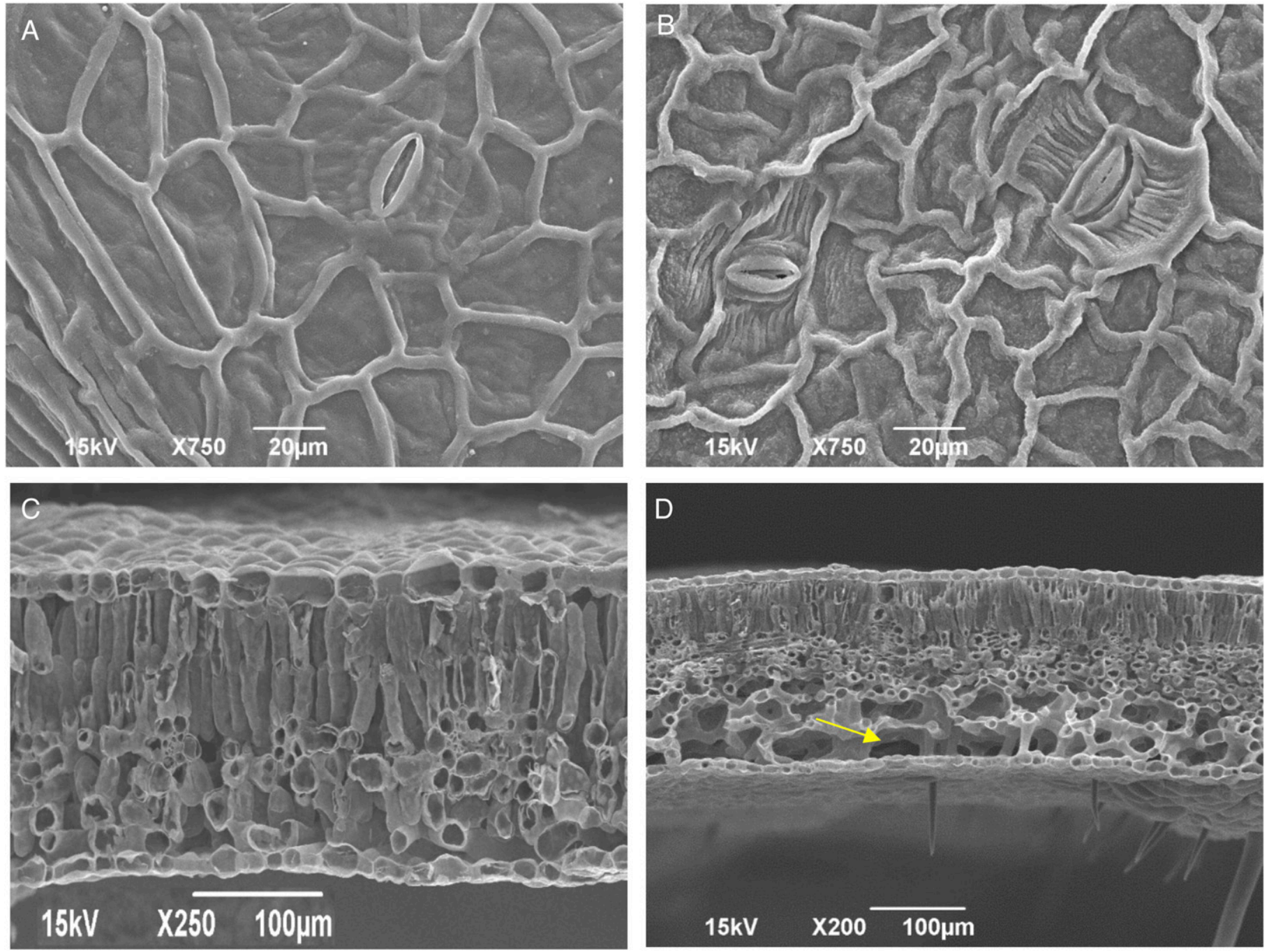

Fig. 1. Scanning electron micrographs of leaves from the moderately resistant DN99 (Populus deltoides $\times$ P. nigra) and susceptible genotype BESC121 ( $P$. trichocarpa) of Populus. A, Surface morphology and C, cross-section of the mock-inoculated moderately resistant genotype. B, Surface morphology and $\mathbf{D}$, crosssection of the mock-inoculated susceptible genotype. Evidence of clearly defined air pockets (gray arrow) in the susceptible genotype. 
D-arabino-1,4-lactone oxidase family protein; and cinnamoyl CoA reductase 1 ; these were upregulated at $1 \mathrm{wpi}$. The expression of six of these genes decreased at later time points relative to the susceptible genotype.
Among the antioxidant genes upregulated in the moderately resistant genotype were glutathione S-transferase, peroxidase, thioredoxin, glutaredoxin family protein, carotenoid cleavage dioxygenase 1, and Plant L-ascorbate oxidase 1 across all time
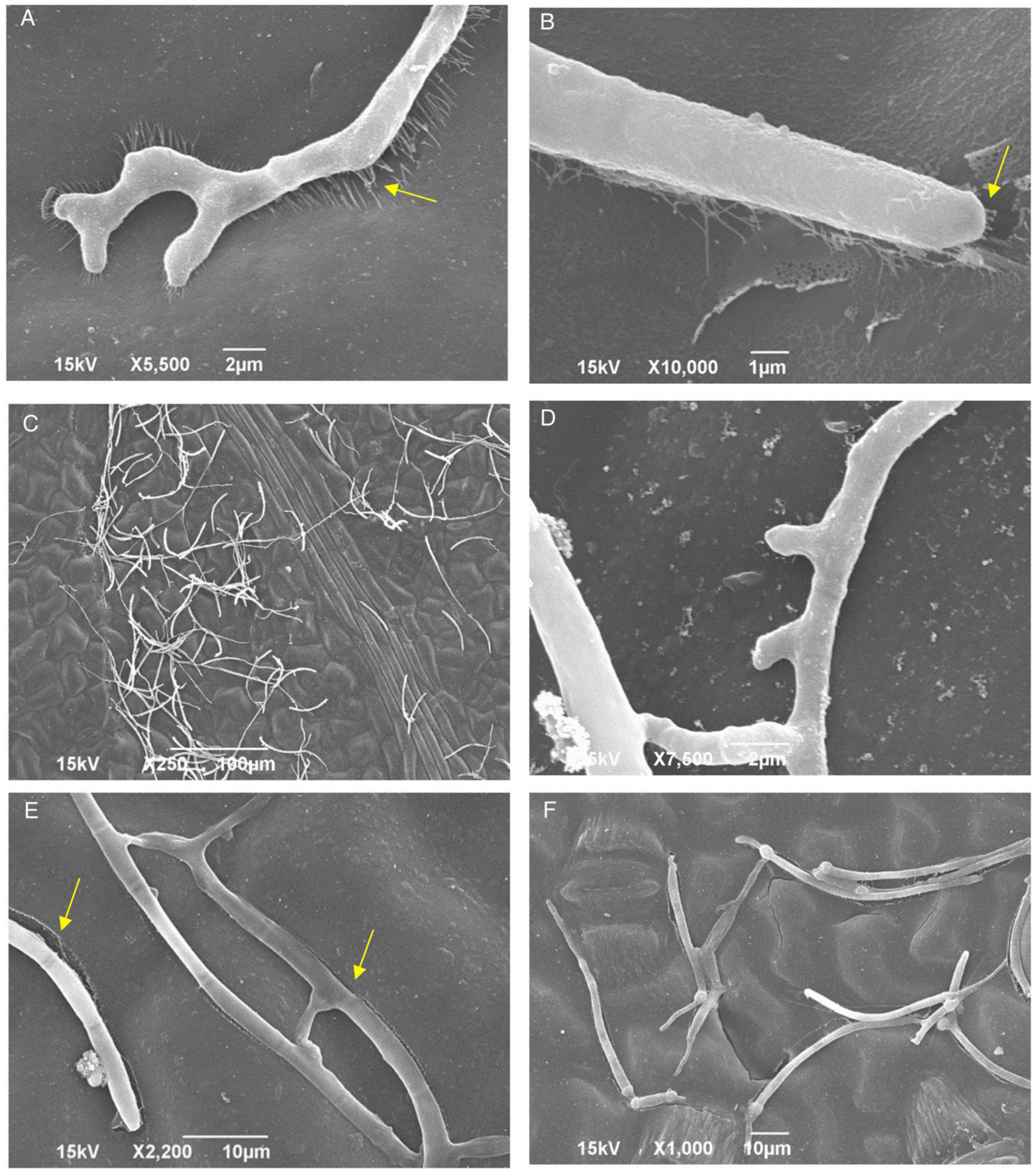

Fig. 2. Scanning electron microscope images of leaves of Populus genotypes inoculated with S. musiva. A, The fibrillar extracellular matrix (ECM) was seen surrounding the conidia and hyphae (gray arrow). B. The ECM at the point of penetration may indicate the presence of cell wall-degrading enzymes. C, Germination of conidia was noted at $48 \mathrm{~h}$ postinoculation, with the growth of germ tubes occurring from various conidia. D, Hypha with multiple branches and an anastomosis. E, Erosion of the cuticle (gray arrow) during germination of conidia and growth of hyphae. F, Swelling on one end of the conidia, which was infrequently observed; if germ tubes arose, then no penetration of the leaf was noted. 
points. The pattern of antioxidant gene expression peaked for the majority of the genes at 1 wpi compared with the susceptible genotype. Several genes were also downregulated at later time points.

The expression of ROS-related genes in the moderately resistant genotype included upregulation of the genes encoding the $F A D$ binding Berberine family protein at $1 \mathrm{wpi}$. Most of these genes were downregulated at 2 wpi compared with the susceptible genotype. At 3 wpi, a peak in expression was seen again. Germin-like protein 1 was downregulated at all time points in the moderately resistant genotype.

In terms of global expression, 113 genes related to defense were upregulated in the moderately resistant genotype at 1 wpi compared with the susceptible genotype. These genes included the following: disease resistance RPMI; disease resistance gene NBS-LRR family; CCNBS-LRR; TIR-NBS-LRR; cytochrome P450 and BCL-2-associated
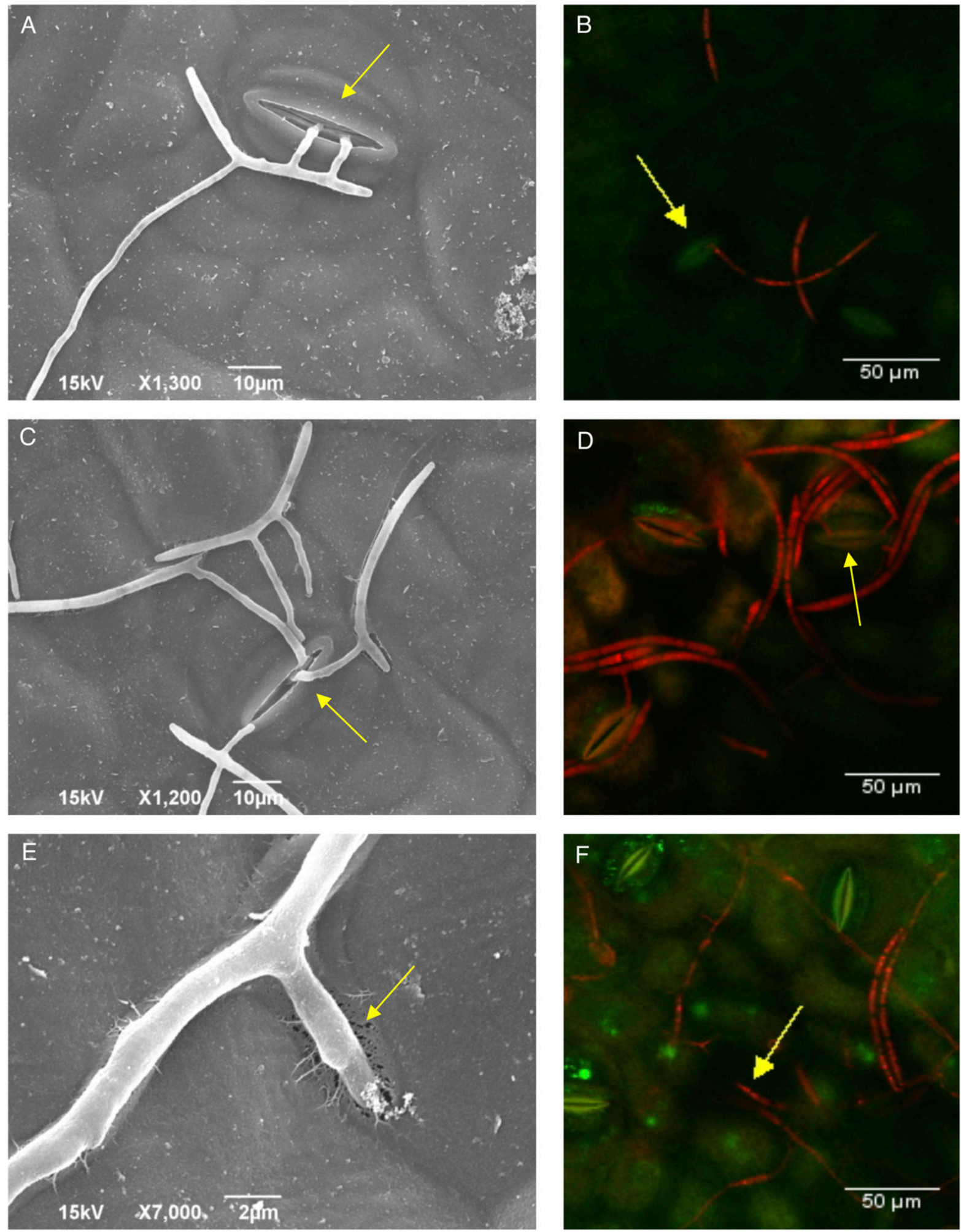

Fig. 3. Modes of penetration of Sphaerulina musiva on inoculated leaves of moderately resistant DN99 (Populus deltoides $\times$ P. nigra), DN34 (P. deltoides $\times$ P. nigra) and susceptible BESC121 (P. trichocarpa), NC11505 (P. maximowczii $\times$ P. trichocarpa) Populus genotypes visualized using scanning electron microscopy and confocal laser scanning microscopy. A and B, Stomatal penetration, and $\mathbf{C}$ and $\mathbf{D}$, occasional multiple penetrations of a stoma were observed. E and $\mathbf{F}$, Germ tubes and hyphae directly penetrating the leaves. Red hyphae in $\mathbf{B}, \mathbf{D}$, and $\mathbf{F}$ are transformed by S. musiva; green autofluorescence is the Populus leaf. 
anthogenes 1, 4, 6; protein of unknown function DUF581; nudix hydrolase; autophagy 3; pathogenesis-related (PR) family protein; PR1; five pathogenesis-related thaumatin super family genes; suppressor of nprl constitutive-like; gene encoding a seven transmembrane MLO family protein; and two NB-ARC domaincontaining disease resistance proteins. These genes remained upregulated at 2 wpi and 3 wpi. Some of the significantly downregulated genes included Avr 9 Cf-9 rapidly elicited genes,
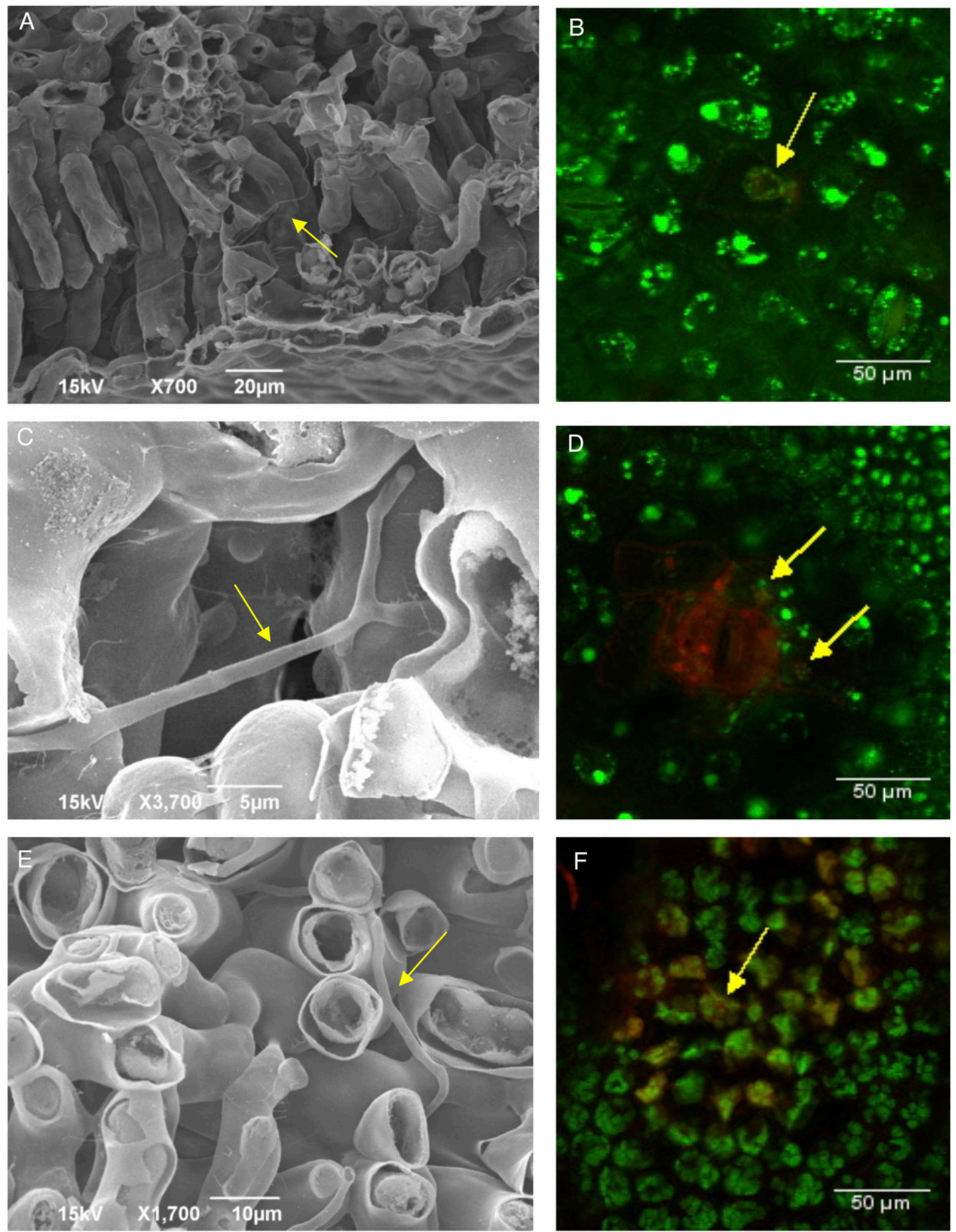

Fig. 4. Postpenetration events of Sphaerulina musiva within inoculated leaves of moderately resistant DN99 (Populus deltoides $\times$ P. nigra) and DN34 (P. deltoides $\times$ P. nigra) and susceptible BESC121 (P. trichocarpa) and NC11505 (P. maximowczii $\times$ P. trichocarpa) Populus genotypes using A, C, and E, cryofracture scanning electron microscopy (cryo-SEM) and $\mathbf{B}, \mathbf{D}$, and $\mathbf{F}$, confocal laser scanning microscopy (LSM). A and $\mathbf{B}$, At 96 h postinoculation, intercellular hyphal growth was observed on palisade mesophyll tissues on both moderately resistant and susceptible genotypes. C and D, At 1 week postinoculation (wpi), in the moderately resistant genotype, hyphal growth was still confined to palisade mesophyll tissues. $\mathbf{E}$ and $\mathbf{F}$, At 1 wpi, in the susceptible genotype, colonization was observed in spongy mesophyll tissues. These observations were consistently seen with LSM and cryo-SEM. B, D, and F, Transformed $S$. musiva are the red hyphae; the uncolonized spongy mesophyll tissues appear as green. 
$C f-4, C f-9$, disease resistance $R G A 4$, senescence-associated gene 21 , an NB-ARC domain-containing disease resistance protein, $M L O 1$, nudix hydrolase homolog 12, beta glucosidase 17, BCL-2 associated anthanogene 3, osmotin 34, cytochrome P450 family
81 and 87, AGD2-like defense response protein 1, and TIRNBS-LRR.

Another notable change in gene expression included the WRKYs that were induced upon pathogen attack. These included WRKY
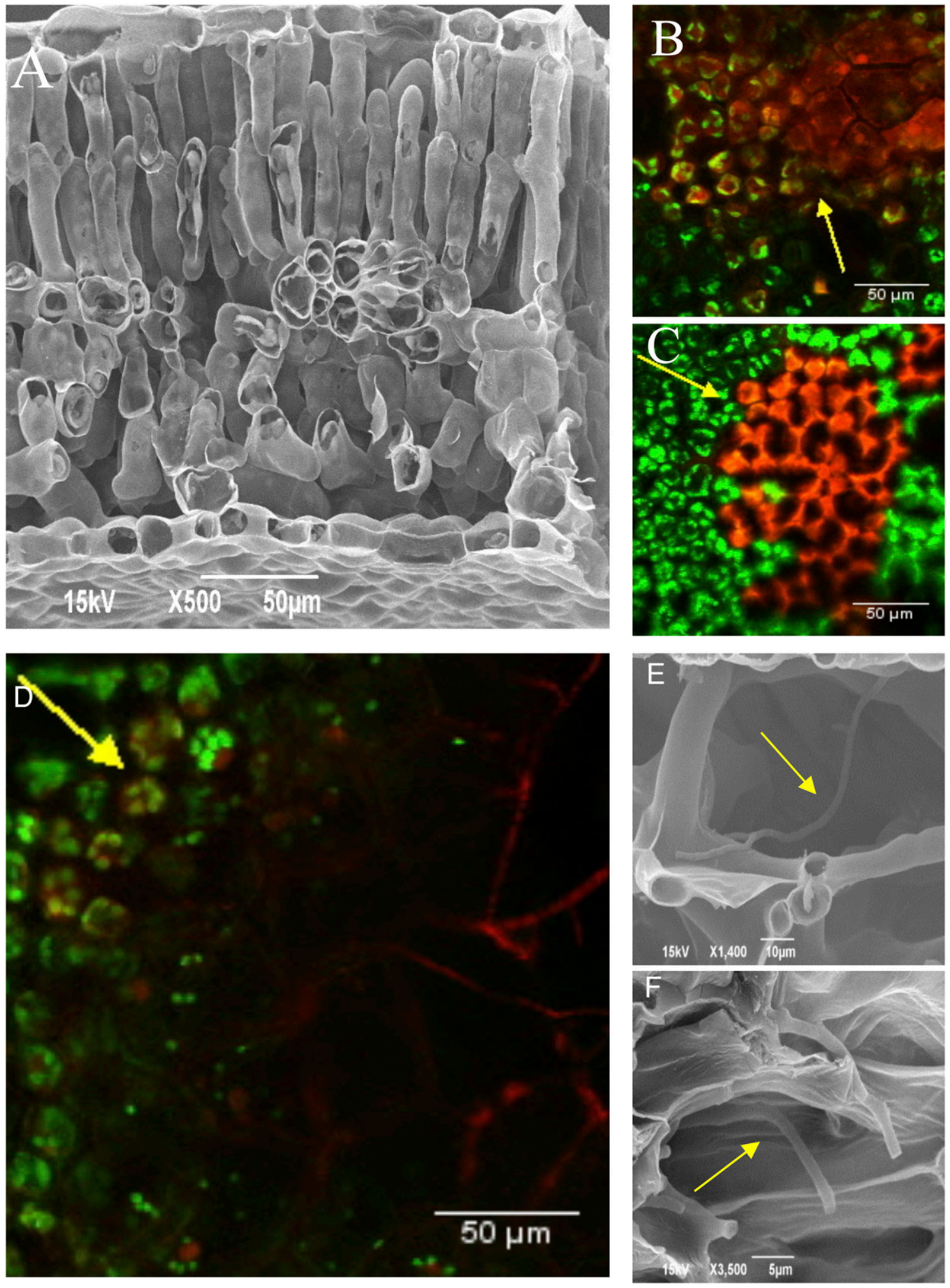

Fig. 5. Postpenetration events of Sphaerulina musiva within inoculated leaves of moderately resistant DN99 (Populus deltoides $\times$ P. nigra) and DN34 (P. deltoides $\times$ $P$. nigra) and susceptible BESC121 (P. trichocarpa) and NC11505 (P. maximowczii $\times$ P. trichocarpa) Populus genotypes using cryofracture scanning electron microscopy (cryo-SEM) and confocal laser scanning microscopy (LSM). A, At 2 weeks postinoculation (wpi), in the moderately resistant genotype, no hyphal growth was detected with cryo-SEM in the spongy mesophyll tissues. B, LSM revealed the beginning of cell death (white arrow) with sparse colonization (yellow arrow) of spongy mesophyll by the fungus in the moderately resistant genotype. $\mathbf{C}$, At 3 wpi, complete cell death was seen in spongy mesophyll tissue of the moderately resistant genotype. F, At 2 wpi and 3 wpi, intercellular colonization and $\mathbf{D}$, intracellular colonization of spongy mesophyll tissues beneath the lesions, E, and air pockets were seen in the susceptible genotype. B and D, Transformed S. musiva appears as red hyphae; dead or dying cells in the spongy mesophyll tissue appear bright red; and the uncolonized spongy mesophyll tissue is green. 
DNA-binding protein 75 and 23, which were upregulated at 3 wpi in the moderately resistant genotype. However, WRKY40 was downregulated at all time points, whereas WRKY28 and WRKY75 were downregulated only at 2 wpi. We also observed upregulation of genes involved in terpenoid, phenylpropanoids, lignin, and MVA pathways at all time points in the moderately resistant genotype compared with the susceptible genotype.
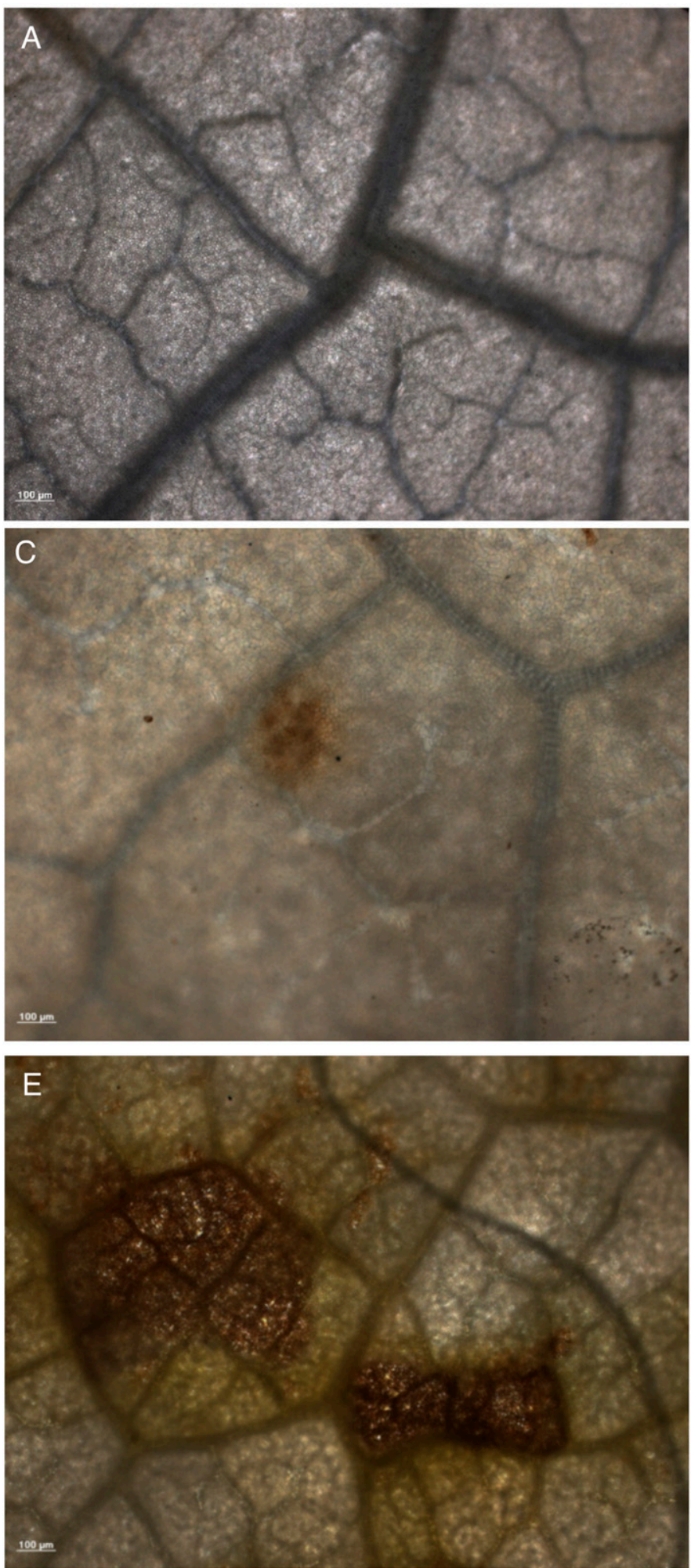

\section{DISCUSSION}

This was the first microscopic study of leaves from moderately resistant and susceptible Populus species inoculated with S. musiva. The main objective was to characterize the mode of adhesion, germination, and penetration of the fungus. In the early stages of infection, a fungal ECM, a network of fibrils at the region of contact
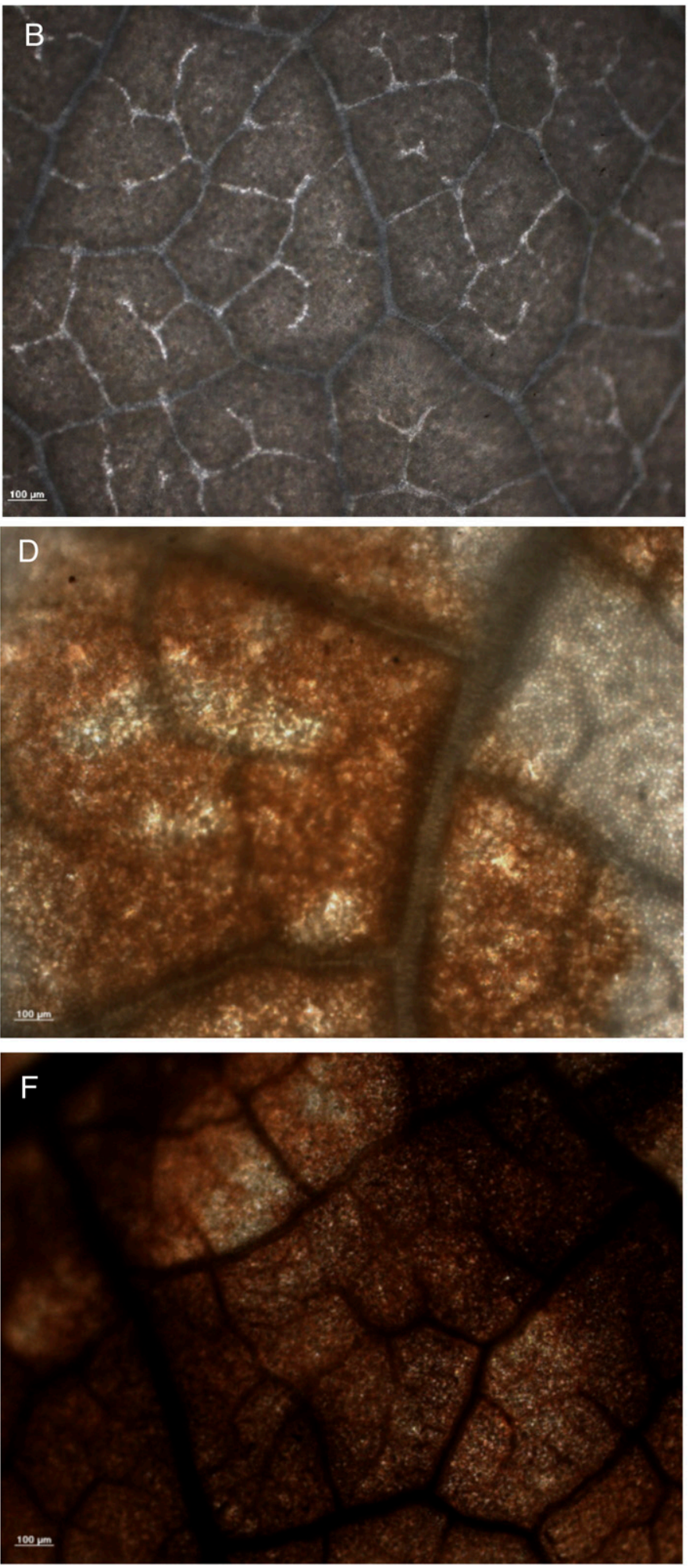

Fig. 6. $\mathrm{H}_{2} \mathrm{O}_{2}$ production detected with the diaminobenzidine (DAB) stain in Populus leaves inoculated with Sphaerulina musiva. A and B, Noninoculated moderately resistant and susceptible genotypes, respectively. $\mathbf{C}$ and $\mathbf{D}$, DAB staining on inoculated moderately resistant and susceptible leaves at 1 week postinoculation (wpi). E and F, DAB staining on moderately resistant and susceptible leaves, respectively, at 3 wpi. Dark brown coloring indicates DAB staining of $\mathrm{H}_{2} \mathrm{O}_{2}$. 
with the leaf, was observed surrounding ungerminated conidia, germ tubes, and hyphae. This pattern suggested a role in adhesion (Castle et al. 1996). The ECM of plant-pathogenic fungi has many roles, including the prevention of desiccation and creation of a favorable environment for the fungus, and it may contain cell wall-degrading enzymes such as cutinases and esterases (Epstein and Nicholson 1997; Nicholson 1996). The apparent erosion or dissolution of the cell wall and cuticular waxes observed indicated that the $S$. musiva ECM likely contains such enzymes.

Following adhesion and germination, S. musiva penetrates the host through the stomata and directly through the cell wall. Initially, germ tubes grew undirected across leaf surfaces, similar to that observed for Zymoseptoria tritici (Kema et al. 1996), Quambalaria sp. (Pegg et al. 2009), and S. musiva on poplar stems (Qin and LeBoldus 2014). The germ tubes did not appear to be attracted to stomata. In many cases, they grew over an open stoma without attempted penetration. Although $S$. musiva did not appear to penetrate closed stomata, there has been evidence (De Wit 1977; Rathaiah 1976) that penetration of closed stomata by leaf-infecting fungal pathogens does occur. Prepenetration differences were not apparent between the moderately resistant and susceptible Populus spp. in the present study.

In contrast to the prepenetration process, postpenetration differences in pathogen colonization were evident by $1 \mathrm{wpi}$. At that time point $S$. musiva was unable to colonize the spongy mesophyll cells of the moderately resistant genotype compared with extensive colonization observed in the susceptible genotype. This difference may be because of the development of a physical barrier or cell wall modification that prevents pathogen colonization (Hückelhoven 2007). Transcriptional responses observed in this study support this hypothesis. Genes annotated as plant invertase/pectin methyl esterase inhibitors and genes involved in cell wall modification such as cellulase 2, cellulose synthase, pectin lyase, and pectin methyl esterase were upregulated at 1 wpi in the moderately resistant genotype. In addition, genes annotated for lignin biosynthesis (laccase 17) and wax synthesis (3-ketoacyl-CoA synthase 1) were also upregulated, suggesting that lignin and wax deposition during $S$. musiva infection further strengthened the cell wall and limited pathogen colonization (Azaiez et al. 2009; Todd et al. 1999). This change in gene expression was correlated with that shown in Figure 4C.

The patterns described here are consistent with those described by other transcriptome studies of $S$. musiva leaf infection. For example, upregulation of beta glucosidase was observed at $1 \mathrm{dpi}$ and 4 dpi in resistant $P$. deltoides and DN34 (Foster et al. 2015), respectively. Differential expression of the laccase gene at $15 \mathrm{dpi}$ in $P$. deltoides and at 4 dpi in NM6 (Liang et al. 2014) was noted. Upregulation of lignin biosynthesis and other cell wall modification pathways was observed across all time points $(1,2$, and 3 wpi) in the

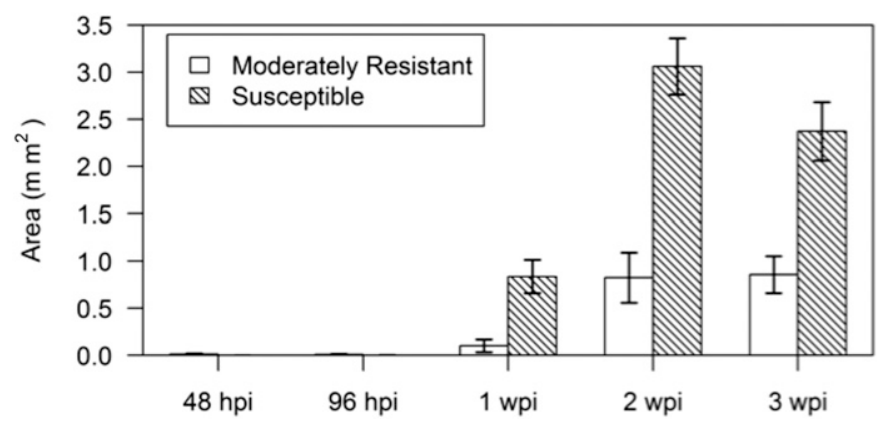

Fig. 7. Mean area of $\mathrm{H}_{2} \mathrm{O}_{2}$ accumulation in leaves of moderately resistant DN34 (Populus deltoides $\times$ P. nigra) and susceptible NC111505 (P. maximowczii $\times$ P. trichocarpa) Populus genotypes inoculated with Sphaerulina musiva at $48 \mathrm{~h}$ postinoculation (hpi), $96 \mathrm{hpi}, 1$ week postinoculation (wpi), 2 wpi, and 3 wpi. Error bars represent the standard deviation $(n=5)$. moderately resistant genotype. This correlated with the observed reduction in colonization of leaf tissue, suggesting that the moderately resistant genotype was constantly repairing or modifying its cell wall to either re-establish structural integrity or prevent colonization. In contrast, upregulation of genes involved in cell wall modification was not observed in the susceptible genotype until later time points. The lack of a strong physical barrier at early time points, as evidenced by the absence of changes in the expression of cell wall-modifying genes, may have facilitated faster colonization of the pathogen in leaf tissue (Fig. 4F). We hypothesized that extensive colonization by the pathogen at 1 wpi may have enabled it to overcome the weak or delayed defense response of the susceptible genotype.

One way to measure the speed and amplitude of a defense response is to directly quantify ROS production, which is one of the hallmarks of pathogen-triggered immunity (PTI). The generation of ROS leads to programed cell death, cell wall strengthening, and other defense responses (Wen et al. 2013). The amount of $\mathrm{H}_{2} \mathrm{O}_{2}$ measured by DAB is typically used as a measure of ROS production. DAB staining was similar for the moderately resistant and susceptible genotypes at the early time points. However, by 2 wpi, DAB staining was more pronounced in the susceptible genotype. The most likely explanation for this pattern was that by 2 wpi, pathogen growth was arrested in the moderately resistant genotype, whereas it continued in the susceptible genotype. This was corroborated by the differences noted in terms of gene expression. For example, $10 \mathrm{FAD}$-binding Berberine family proteins were upregulated in the moderately resistant genotype at 1 wpi. Berberine proteins generate $\mathrm{H}_{2} \mathrm{O}_{2}$ and are known to produce antifungal compounds. The early response of several ROS-related genes in the moderately resistant genotype compared with the susceptible genotype at the same time point (1 wpi) suggested that ROS may be involved in disease resistance.

Several antioxidants encoding genes were upregulated in the moderately resistant genotype compared with the susceptible genotype, including catalases, peroxidases, GST, and thioredoxin at 1 wpi, suggesting that antioxidants may be delaying cell death by detoxification and, subsequently, slowing the spread of $S$. musiva. Some of these enzymes (peroxidase, for example) also help to generate ROS that are toxic to the pathogen (Arfaoui et al. 2007; Daayf et al. 2003; El Hadrami et al. 1997; Wen et al. 2013). This could explain the formation of smaller lesions observed in the moderately resistant genotype at the later time points. However, in the susceptible genotype, lesions continued to grow larger at the later time point, which was correlated with the lower level of antioxidant coding genes in the susceptible genotype.

As expected, upregulation of genes encoding PR family proteins, such as $P R l$ and thaumatin, were seen in the moderately resistant genotype compared with the susceptible genotype at 1 wpi. At later time points, expression of these genes was similar in the moderately resistant and susceptible genotypes. PR proteins have antimicrobial activity and can hydrolyze pathogen cell walls, disrupt the membrane, or affect fungal physiology (Wang et al. 2005, 2006). Other notable genes putatively involved in antimicrobial activity in the moderately resistant genotype included antimicrobial compounds (serine carboxypeptidase-like 18 and 28), dirigent-like proteins, and diacylglycerol kinase 5.

An intriguing observation in the pattern of gene expression in the moderately resistant genotype was the activation of defense genes leading to cell death, as well as genes leading to cell survival. The increased expression of genes mediating cell death in both the moderately resistant (TIR-NBS LRRs, disease resistance RPMIlike, NBS-LRR family, CC-NBS-LRR, genes like ACD1, and Arabinogalactan protein 26$)$ and susceptible genotype (Avr $9 / C f 9$ elicited genes, disease resistance $R G A 4, C f-4,9$ disease resistancelike) was observed. These genes probably have a role in R-genemediated cell death. However, in the moderately resistant genotype, several genes known to be involved in cell survival (BCL2-associated 
anthanogene, APG 3, HMG box protein, MLO1, MLO4, nudix hydrolase, and seven transmembrane MLO-like proteins) were observed. Expression of only three of these genes was found in the susceptible genotype. The rapid change in the moderately resistant genotype relative to the susceptible genotype indicated faster recovery from infection, supporting our hypothesis that susceptibility is largely a function of a slow and delayed defense response in the susceptible genotype.

In summary, S. musiva, upon adhering to Populus leaves, penetrates through the stomata or has direct penetration (by $48 \mathrm{hpi}$ ). Subsequently, colonization of palisade mesophyll cells occurs (96 hpi). No differences in postpenetration events were evident between genotypes until 1 wpi. At that time point, colonization of spongy mesophyll cells was apparent in the susceptible genotypes and absent in the moderately resistant genotype. Several factors preventing this colonization were hypothesized based on the RNA-seq results. At 1 wpi, in the moderately resistant genotype, there was a peak in the expression of genes annotated for cell wall remodeling, ROS production, antioxidants, defense-related genes, and PR protein expression, all of which lead to rapid death of the spongy mesophyll cells, preventing further colonization at 2 wpi and 3 wpi. In contrast, the colonization of living spongy mesophyll cells observed in the susceptible genotype at 1 wpi was associated with reduced defense gene expression and cell wall modeling. We hypothesized that these differences enabled fungal ramification in the susceptible genotype, leading to continued colonization and disease development over time. This study has provided the first linkage between microscopic, biochemical, and molecular responses of moderately resistant and susceptible genotypes of Populus to S. musiva.

\section{ACKNOWLEDGMENTS}

We thank C. Doetkott for technical assistance. We also thank A. Alhashel for his assistance in the greenhouse. Many thanks to $S$. Kang for providing the vector, and to J. Moore and S. Payne for their guidance and expertise using SEM and cryofracture SEM.

\section{LITERATURE CITED}

Arfaoui, A., El Hadrami, A., Mabrouk, Y., Sifi, B., Boudabous, A., El Hadrami, I., Daayf, F., and Chérif, M. 2007. Treatment of chickpea with Rhizobium isolates enhances the expression of phenylpropanoid defenserelated genes in response to infection by Fusarium oxysporum f. sp. ciceris. Plant Physiol. Biochem. 45:470-479.

Azaiez, A., Boyle, B., Levée, V., and Séguin, A. 2009. Transcriptome profiling in hybrid poplar following interactions with Melampsora rust fungi. Mol. Plant-Microbe Interact. 22:190-200.

Callan, B., Leal, I., Foord, B., Dennis, J., and Van Oosten, C. 2007. Septoria musiva isolated from cankered stems in hybrid poplar stool beds, Fraser Valley, British Columbia. N. Am. Fungi 2:1-9.

Castle, A. J., Stocco, N., and Boulianne, R. 1996. Fimbrial-dependent mating in Microbotryum violaceum involves a mannose-lectin interaction. Can. J. Microbiol. 42:461-466.

Daayf, F., El Bellaj, M., El Hassni, M., J'aiti, F., and El Hadrami, I. 2003. Elicitation of soluble phenolics in date palm (Phoenix dactylifera) callus by Fusarium oxysporum f. sp. albedinis culture medium. Environ. Exp. Bot. 49:41-47.

De Wit, P. J. 1977. A light and scanning-electron microscopic study of infection of tomato plants by virulent and avirulent races of Cladosporium fulvum. Neth. J. Plant Pathol. 83:109-122.

Dhillon, B., Feau, N., Aerts, A. L., Beauseigle, S., Bernier, L., Copeland, A., Foster, A., Gill, N., Henrissat, B., Herath, P., LaButti, K. M., Levasseur, A., Lindquist, E. A., Majoor, E., Ohm, R. A., Pangilinan, J. L., Pribowo, A., Saddler, J. N., Sakalidis, M. L., de Vries, R. P., Grigoriev, I. V., Goodwin, S. B., Tanguay, P., and Hamelin, R. C. 2015. Horizontal gene transfer and gene dosage drives adaptation to wood colonization in a tree pathogen. Proc. Natl. Acad. Sci. 112:3451-3456.

Duplessis, S., Cuomo, C. A., Lin, Y.-C., Aerts, A., Tisserant, E., Veneault-Fourrey, C., Joly, D. L., Hacquard, S., Amselem, J., Cantarel, B. L., Chiu, R., Coutinho, P. M., Feau, N., Field, M., Frey, P., Gelhaye, E., Goldberg, J., Grabherr, M. G., Kodira, C. D., Kohler, A., Kües, U., Lindquist, E. A., Lucas, S. M., Mago, R., Mauceli, E., Morin, E., Murat, C., Pangilinan, J. L., Park, R., Pearson, M., Quesneville, H., Rouhier, N.,
Sakthikumar, S., Salamov, A. A., Schmutz, J., Selles, B., Shapiro, H., Tanguay, P., Tuskan, G. A., Henrissat, B., Van de Peer, Y., Rouzé, P., Ellis, J. G., Dodds, P. N., Schein, J. E., Zhong, S., Hamelin, R. C., Grigoriev, I. V., Szabo, L. J., and Martin, F. 2011. Obligate biotrophy features unraveled by the genomic analysis of rust fungi. Proc. Natl. Acad. Sci. 108:9166-9171.

El Hadrami, A., Islam, M., Adam, L. R., and Daayf, F. 2015. A cupin domaincontaining protein with a quercetinase activity (VdQase) regulates Verticillium dahliae's pathogenicity and contributes to counteracting host defenses. Front. Plant Sci. 6:440.

El Hadrami, I., Ramos, T., El Bellaj, M., El Idrissi-Tourane, A., and Macheix, J. 1997. A sinapic derivative as an induced defence compound of date palm against Fusarium oxysporum f. sp. albedinis, the agent causing bayoud disease. J. Phytopathol. 145:329-333.

Epstein, L., and Nicholson, R. 1997. Adhesion of spores and hyphae to plant surfaces. Pages 11-25 in: Plant Relationships. G. C. Carroll and P. Tudzynski, eds. Springer, Boston, MA.

Feau, N., Mottet, M.-J., Périnet, P., Hamelin, R. C., and Bernier, L. 2010. Recent advances related to poplar leaf spot and canker caused by Septoria musiva. Can. J. Plant Pathol. 32:122-134.

Foster, A., Morency, M., Séguin, A., and Tanguay, P. 2014. Agrobacterium tumefaciens-mediated transformation for targeted disruption and over expression of genes in the poplar pathogen Sphaerulina musiva. For. Pathol. 44:233-241.

Foster, A. J., Pelletier, G., Tanguay, P., and Séguin, A. 2015. Transcriptome analysis of poplar during leaf spot infection with Sphaerulina spp. PLoS One 10:e0138162.

Gönner, M. V., and Schlösser, E. 1993. Oxidative stress in interactions between Avena sativa L. and Drechslera spp. Physiol. Mol. Plant Pathol. 42: 221-234.

Govrin, E. M., and Levine, A. 2000. The hypersensitive response facilitates plant infection by the necrotrophic pathogen Botrytis cinerea. Curr. Biol. 10:751-757.

Grant, J. J., and Loake, G. J. 2000. Role of reactive oxygen intermediates and cognate redox signaling in disease resistance. Plant Physiol. 124:21-30.

He, C., Zheng, S., Zhang, J., Duan, A., Zeng, Y., Cui, K., and Sederoff, R. 2010. Clonal reproduction and natural variation of Populus canescens patches. Tree Physiol. 30:1383-1390.

Hsu, C.-Y., Adams, J. P., Kim, H., No, K., Ma, C., Strauss, S. H., Drnevich, J., Vandervelde, L., Ellis, J. D., Rice, B. M., Wickett, N., Gunter, L. E., Tuskan, G. A., Brunner, A. M., Page, G. P., Barakat, A., Carlson, J. E., dePamphilis, C. W., Luthe, D. S., and Yuceer, C. 2011. FLOWERING LOCUST duplication coordinates reproductive and vegetative growth in perennial poplar. Proc. Natl. Acad. Sci. 108:10756-10761.

Hückelhoven, R. 2007. Cell wall-associated mechanisms of disease resistance and susceptibility. Annu. Rev. Phytopathol. 45:101-127.

Hückelhoven, R., Fodor, J., Preis, C., and Kogel, K. H. 1999. Hypersensitive cell death and papilla formation in barley attacked by the powdery mildew fungus are associated with hydrogen peroxide but not with salicylic acid accumulation. Plant Physiol. 119:1251-1260.

Jansson, S., and Douglas, C. J. 2007. Populus: A model system for plant biology. Annu. Rev. Plant Biol. 58:435-458.

Jung, K., Friede, T., and Beißbarth, T. 2011. Reporting FDR analogous confidence intervals for the $\log$ fold change of differentially expressed genes. BMC Bioinformatics 12:288.

Kema, G. H., Yu, D., Rijkenberg, F. H., Shaw, M. W., and Baayen, R. P. 1996. Histology of the pathogenesis of Mycosphaerella graminicola in wheat. Phytopathology 86:777-786.

Khang, C. H., Park, S.-Y., Rho, H.-S., Lee, Y.-H., and Kang, S. 2006. Filamentous fungi (Magnaporthe grisea and Fusarium oxysporum). Pages 403-420 in: Agrobacterium Protocols. Volume 2. K. Wang, ed. Humana Press.

Lamb, C., and Dixon, R. A. 1997. The oxidative burst in plant disease resistance. Annu. Rev. Plant Biol. 48:251-275.

LeBoldus, J. M., Blenis, P. V., and Thomas, B. R. 2010. A method to induce stem cankers by inoculating nonwounded populus clones with Septoria musiva spore suspensions. Plant Dis. 94:1238-1242.

LeBoldus, J. M., Kinzer, K., Richards, J., Ya, Z., Yan, C., Friesen, T. L., and Brueggeman, R. 2015. Genotype-by-sequencing of the plant-pathogenic fungi Pyrenophora teres and Sphaerulina musiva utilizing Ion Torrent sequence technology. Mol. Plant Pathol. 16:623-632.

Levine, A., Tenhaken, R., Dixon, R., and Lamb, C. 1994. $\mathrm{H}_{2} \mathrm{O}_{2}$ from the oxidative burst orchestrates the plant hypersensitive disease resistance response. Cell 79:583-593.

Liang, H., Staton, M., Xu, Y., Xu, T., and LeBoldus, J. 2014. Comparative expression analysis of resistant and susceptible Populus clones inoculated with Septoria musiva. Plant Sci. 223:69-78.

Luley, C. J., and McNabb, H. S., Jr. 1989. Ascospore production, release, germination, and infection of Populus by Mycosphaerella populorum. Phytopathology 79:1013-1018. 
Martin, F., Aerts, A., Ahrén, D., Brun, A., Danchin, E. G. J., Duchaussoy, F., Gibon, J., Kohler, A., Lindquist, E., Pereda, V., Salamov, A., Shapiro, H. J., Wuyts, J., Blaudez, D., Buée, M., Brokstein, P., Canbäck, B., Cohen, D., Courty, P. E., Coutinho, P. M., Delaruelle, C., Detter, J. C., Deveau, A., DiFazio, S., Duplessis, S., Fraissinet-Tachet, L., Lucic, E., Frey-Klett, P., Fourrey, C., Feussner, I., Gay, G., Grimwood, J., Hoegger, P. J., Jain, P., Kilaru, S., Labbé, J., Lin, Y. C., Legué, V., Le Tacon, F., Marmeisse, R., Melayah, D., Montanini, B., Muratet, M., Nehls, U., Niculita-Hirzel, H., Secq, M. P. O.-L., Peter, M., Quesneville, H., Rajashekar, B., Reich, M., Rouhier, N., Schmutz, J., Yin, T., Chalot, M., Henrissat, B., Kües, U., Lucas, S., Van de Peer, Y., Podila, G. K., Polle, A., Pukkila, P. J., Richardson, P. M., Rouzé, P., Sanders, I. R., Stajich, J. E., Tunlid, A., Tuskan, G., and Grigoriev, I. V. 2008. The genome of Laccaria bicolor provides insights into mycorrhizal symbiosis. Nature 452:88-92.

Meilan, R. 1997. Floral induction in woody angiosperms. New For. 14: 179-202.

Mellersh, D. G., Foulds, I. V., Higgins, V. J., and Heath, M. C. 2002. $\mathrm{H}_{2} \mathrm{O}_{2}$ plays different roles in determining penetration failure in three diverse plant-fungal interactions. Plant J. 29:257-268.

Miranda, M., Ralph, S. G., Mellway, R., White, R., Heath, M. C., Bohlmann, J., and Constabel, C. P. 2007. The transcriptional response of hybrid poplar (Populus trichocarpa $\times$ P. deltoids) to infection by Melampsora medusae leaf rust involves induction of flavonoid pathway genes leading to the accumulation of Proanthocyanidins. Mol. Plant-Microbe Interact. 20:816-831.

Moore, J. A., and Payne, S. A. 2012. Freeze-fracture of infected plant leaves in ethanol for scanning electron microscopic study of fungal pathogens. Pages 107-119 in: Plant Fungal Pathogens. M. Bolton and B. Thomma, eds. Humana Press.

Muchero, W., Sondreli, K. L., Chen, J.-G., Urbanowicz, B. R., Zhang, J., Singan, V., Yang, Y., Brueggeman, R. S., Franco-Coronado, J., Abraham, N., Yang, J.-Y., Moremen, K. W., Weisberg, A. J., Chang, J. H., Lundquist, E., Barry, K., Ranjan, P., Jawdy, S., Schmutz, J., Tuskan, G. A., and LeBoldus, J. M. 2018. Association mapping, transcriptomics, and transient expression identify candidate genes mediating plant-pathogen interactions in a tree. Proc. Natl. Acad. Sci. 115:11573-11578.

Nicholson, R. L. 1996. Adhesion of fungal propagules: significance to the success of the fungal infection process. Pages 117-134 in: Histology ultrastructure and molecular cytology of plant-microorganism interactions. M. Nicole and V. Gianinazzi-Pearson, eds. Springer, Dordrecht.

Orczyk, W., Dmochowska-Boguta, M., Czembor, H., and Nadolska-Orczyk, A. 2010. Spatiotemporal patterns of oxidative burst and micronecrosis in resistance of wheat to brown rust infection. Plant Pathol. 59:567-575.

Ostry, M. 1987. Biology of Septoria musiva and Marssonina brunnea in hybrid Populus plantations and control of Septoria canker in nurseries. Eur. J. Forest Pathol. 17:158-165.

Pegg, G. S., Webb, R., Carnegie, A., Wingfield, M., and Drenth, A. 2009. Infection and disease development of Quambalaria spp. on Corymbia and Eucalyptus species. Plant Pathol. 58:642-654.

Qin, R., and LeBoldus, J. M. 2014. The infection biology of Sphaerulina musiva: Clues to understanding a forest pathogen. PLoS One 9:e103477.

Rathaiah, Y. 1976. Infection of sugarbeet by Cercospora beticola in relation to stomatal condition. Phytopathology 66:737-740.

Rennenberg, H., Wildhagen, H., and Ehlting, B. 2010. Nitrogen nutrition of poplar trees. Plant Biol. 12:275-291.

Sakalidis, M. L., Feau, N., Dhillon, B., and Hamelin, R. C. 2016. Genetic patterns reveal historical and contemporary dispersal of a tree pathogen. Biol. Invasions 18:1781-1799.

Shinogi, T., Suzuki, T., Kurihara, T., Narusaka, Y., and Park, P. 2003. Microscopic detection of reactive oxygen species generation in the compatible and incompatible interactions of Alternaria alternata Japanese pear pathotype and host plants. J. Gen. Plant Pathol. 69:7-16.
Sinclair, W., Lyon, H., and Johnson, W. 1987. Diseases of Trees and Shrubs. Cornell University Press, Ithaca, NY.

Sivanesan, A. 1990. CMI description sheets: Set 99. Mycopathologia 109: 41-62.

Thordal-Christensen, H., Zhang, Z., Wei, Y., and Collinge, D. B. 1997. Subcellular localization of $\mathrm{H} 2 \mathrm{O} 2$ in plants. $\mathrm{H} 2 \mathrm{O} 2$ accumulation in papillae and hypersensitive response during the barley-powdery mildew interaction. Plant J. 11:1187-1194.

Tiedemann, A. V. 1997. Evidence for a primary role of active oxygen species in induction of host cell death during infection of bean leaves with Botrytis cinerea. Physiol. Mol. Plant Pathol. 50:151-166.

Todd, J., Post-Beittenmiller, D., and Jaworski, J. G. 1999. KCS1 encodes a fatty acid elongase 3-ketoacyl-CoA synthase affecting wax biosynthesis in Arabidopsis thaliana. Plant J. 17:119-130.

Tuskan, G. A., DiFazio, S., Jansson, S., Bohlmann, J., Grigoriev, I., Hellsten, U., Putnam, N., Ralph, S., Rombauts, S., Salamov, A., Schein, J., Sterck, L., Aerts, A., Bhalerao, R. R., Bhalerao, R. P., Blaudez, D., Boerjan, W., Brun, A., Brunner, A., Busov, V., Campbell, M., Carlson, J., Chalot, M., Chapman, J., Chen, G. L., Cooper, D., Coutinho, P. M., Couturier, J., Covert, S., Cronk, Q., Cunningham, R., Davis, J., Degroeve, S., Déjardin, A., dePamphilis, C., Detter, J., Dirks, B., Dubchak, I., Duplessis, S., Ehlting, J., Ellis, B., Gendler, K., Goodstein, D., Gribskov, M., Grimwood, J., Groover, A., Gunter, L., Hamberger, B., Heinze, B., Helariutta, Y., Henrissat, B., Holligan, D., Holt, R., Huang, W., Islam-Faridi, N., Jones, S., Jones-Rhoades, M., Jorgensen, R., Joshi, C., Kangasjärvi, J., Karlsson, J., Kelleher, C., Kirkpatrick, R., Kirst, M., Kohler, A., Kalluri, U., Larimer, F., Leebens-Mack, J., Leplé, J. C., Locascio, P., Lou, Y., Lucas, S., Martin, F., Montanini, B., Napoli, C., Nelson, D. R., Nelson, C., Nieminen, K., Nilsson, O., Pereda, V., Peter, G., Philippe, R., Pilate, G., Poliakov, A., Razumovskaya, J., Richardson, P., Rinaldi, C., Ritland, K., Rouzé, P., Ryaboy, D., Schmutz, J., Schrader, J., Segerman, B., Shin, H., Siddiqui, A., Sterky, F., Terry, A., Tsai, C. J., Uberbacher, E., Unneberg, P., Vahala, J., Wall, K., Wessler, S., Yang, G., Yin, T., Douglas, C., Marra, M., Sandberg, G., Van de Peer, Y., and Rokhsar, D. 2006. The genome of black cottonwood, Populus trichocarpa (Torr. \& Gray). Science 313:1596-1604.

Wang, C. F., Huang, L. L., Buchenauer, H., Han, Q. M., Zhang, H. C., and Kang, Z. S. 2007. Histochemical studies on the accumulation of reactive oxygen species $\left(\mathrm{O}_{2}-\right.$ and $\left.\mathrm{H}_{2} \mathrm{O}_{2}\right)$ in the incompatible and compatible interaction of wheat-Puccinia striiformis f. sp. tritici. Physiol. Mol. Plant Pathol. 71:230-239.

Wang, D., Amornsiripanitch, N., and Dong, X. 2006. A genomic approach to identify regulatory nodes in the transcriptional network of systemic acquired resistance in plants. PLoS Pathog 2:e123.

Wang, D., Weaver, N. D., Kesarwani, M., and Dong, X. 2005. Induction of protein secretory pathway is required for systemic acquired resistance. Science 308:1036-1040.

Weiland, J. E., and Stanosz, G. R. 2007. The histology of hybrid poplar clones inoculated with Septoria musiva. Plant Dis. 91:1524-1530.

Weiland, J. E., Stanosz, J. C., and Stanosz, G. R. 2003. Prediction of long-term canker disease damage from the responses of juvenile poplar clones to inoculation with Septoria musiva. Plant Dis. 87:1507-1514.

Wen, L., Tan, T.-L., Shu, J.-B., Chen, Y., Liu, Y., Yang, Z.-F., Zhang, Q.-P., Yin, M.-Z., Tao, J., and Guan, C.-Y. 2013. Using proteomic analysis to find the proteins involved in resistance against Sclerotinia sclerotiorum in adult Brassica napus. Eur. J. Plant Pathol. 137:505-523.

Wojtaszek, P. 1997. Oxidative burst: an early plant response to pathogen infection. Biochem. J. 322:681-692.

Zhu, S., Cao, Y.-Z., Jiang, C., Tan, B.-Y., Wang, Z., Feng, S., Zhang, L., Su, X.-H., Brejova, B., Vinar, T., Xu, M., Wang, M.-X., Zhang, S.-G., Huang, M.-R., Wu, R., and Zhou, Y. 2012. Sequencing the genome of Marssonina brunnea reveals fungus-poplar co-evolution. BMC Genomics 13:382. 